\title{
The effects of single aerial 1080 possum-control operations on common forest birds in the South Island, New Zealand
}

\author{
Josh Van Vianen ${ }^{1,2 \dagger}$, Olivia R. Burge ${ }^{1,3 \dagger}$, Archie T. MacFarlane ${ }^{1}$ and Dave Kelly ${ }^{1 *}$ \\ ${ }^{1}$ Centre for Integrative Ecology, School of Biological Sciences, University of Canterbury, Private Bag 4800, Christchurch, \\ New Zealand \\ ${ }^{2}$ Center for International Forestry Research, Bogor 16000, Indonesia \\ ${ }^{3}$ Landcare Research, Lincoln, New Zealand \\ JVV and ORB contributed equally to the manuscript. \\ *Author for correspondence (Email: dave.kelly@canterbury.ac.nz)
}

Published online: 26 February 2018

\begin{abstract}
We used a long-term replicated before-after control-impact (BACI) sampling design to monitor the effect of aerial 1080 possum-control operations on common forest bird populations. Paired treatment and nontreatment sites in the Rolleston Range (East Coast, South Island) and Alexander Range (West Coast, South Island) were monitored once before 1080 treatment during winter 2012 and for three successive summers afterwards. Mammals (possums Trichosurus vulpecula, rats Rattus spp. and mice Mus musculus) were monitored with chew cards, and forest birds with five-minute counts. Possums decreased to negligible levels in treatment sites, but increased over time in non-treatment sites. Rats were only present at the West Coast sites, where there was a significant, but short-lived, decrease post-1080. Mouse abundance showed almost no effects post-1080, but increased at the East Coast sites after a beech (Nothofagus spp.) mast seeding event. No common native bird species showed short-term negative effects post-1080. Three species-tomtit (Petroica macrocephala), silvereye (Zosterops lateralis), grey warbler (Gerygone igata) - increased significantly. Longer-term effects on birds were nearly all neutral or positive, including bellbirds which increased three-fold in treatment areas. In nontreatment areas, higher possum densities were correlated with subsequent decreases in bird counts (averaged across all species). Overall, the one-off aerial 1080 treatment had conservation benefits.
\end{abstract}

Keywords: bird; forest; meso-predator release; Mus musculus; non-target impacts; pest control; possum; Rattus rattus; rodent; sodium fluoroacetate; toxins; Trichosurus vulpecula

\section{Introduction}

In New Zealand, much conservation work consists of controlling introduced pests and weeds to protect biodiversity (Craig et al. 2000). This control can cause controversy, especially when it involves the aerial application of toxins. Although recent reviews found aerially applied 1080 toxin to be relatively safe (ERMA 2007) and even said it should be used more widely (Wright 2011), they also called for better long-term monitoring of the wider effects. In this paper, we report on a 4-year study monitoring two forest sites following aerially applied 1080 .

Sodium fluoroacetate (1080) is widely used in New Zealand to target possums Trichosurus vulpecula, ship rats Rattus rattus, stoats Mustela erminea, and feral cats Felis catus. There has been extensive research into possible nontarget effects of 1080 due to the broad spectrum nature of the toxin (Booth \& Wickstrom 1999; O'Halloran et al. 2005; Suren \& Bonnett 2006; Suren \& Lambert 2006; Veltman \& Westbrooke 2011). Previous work has found direct mortality in some native bird species through bait consumption, including robins Petroica australis (Powlesland et al. 1999), tomtits Petroica macrocephala (Powlesland et al.2000) and kea Nestor notabilis (Veltman \& Westbrooke 2011). Changes to bait type, concentration, and pre-feeding practices are considered to have reduced the effects on non-target species. More recent studies have found that aerial 1080 operations have no direct impacts on a range of taxa, including bird populations (Greene et al. 2013;
Schadewinkel et al. 2014), or that a small level of immediate mortality can be outweighed by subsequent increased survival and breeding success in the absence of predators (van Klink et al. 2013; Elliott \& Kemp 2016). However, much of the research on 1080 impacts has focused on birds of conservation concern including kākā (Nestor meridionalis; Moorhouse et al. 2003; Powlesland et al. 2003), kiwi (Apteryx spp.; Robertson et al. 1999; Gillies et al. 2003), mōhua (Mohoua ochrocephala) and kākāriki (Cyanoramphus spp.; Smith \& Westbrooke 2004).

Our current understanding of the effects of 1080 on common forest species is less well-developed (Veltman \& Westbrooke 2011; but see O'Donnell \& Hoare 2012), despite the fact that some species increase after pest control (Kelly et al. 2005) and some continue to decline in unmanaged areas (Elliott et al. 2010; Innes et al. 2010). Longer-term changes in bird abundance following 1080 remain under-investigated, as most impact studies span short timescales.

This study aimed to examine the longer-term impacts of aerial 1080 on common forest birds in the South Island of New Zealand. We included both native and exotic birds, because changes in density of exotic birds might have indirect effects on natives through altered competition. A 4-year replicated before-after control-impact (BACI) study design was implemented, incorporating both target mammal and non-target bird monitoring. Specifically, we monitored indices of abundance of possums, rats and mice, and based on the literature predicted that both possums and rats would decrease with 1080 treatment, but that possums would be much slower 
to recover. We monitored common birds using bird-call counts, and predicted that we would see increases in most native bird species with the possible exception of silvereyes (Zosterops lateralis) and tomtits (O’Donnell \& Hoare 2012).

\section{Methods}

In winter 2012, bovine tuberculosis ( $\mathrm{Tb}$ ) was detected for the first time in cattle near the Rolleston Range on the eastern side of the South Island of New Zealand (Fig. 1), an area which had never had any prior aerial 1080 operations. At the same time, a routine possum control operation was planned for the Alexander Range on the West Coast of the South Island. The Alexander Range, like much of the lowland central West Coast, has received previous aerial 1080 applications for ongoing bovine Tb control. Therefore, two aerial 1080 operations were undertaken by the Animal Health Board (now OSPRI) during winter 2012 in the Alexander Range $\left(42^{\circ} 43.0^{\prime} \mathrm{S}, 171^{\circ} 35.2^{\prime}\right.$ $\mathrm{E})$, and in the Rolleston Range $\left(43^{\circ} 10.8^{\prime} \mathrm{S}, 171^{\circ} 18.1^{\prime} \mathrm{E}\right)$.

Baseline bird and mammal monitoring was undertaken during the winter just prior to treatment (winter 2012) and for three successive summers. The lack of a pre-treatment summer dataset was addressed by pairing each treatment site with a nearby non-treatment site of similar vegetation and altitude (Fig. 1). Any 1080 effect would then be seen not by a change over time within a treatment site, but by a significant time $x$ treatment interaction. A significant main effect of time shows that treated and untreated sites changed the same way over time, and a significant main effect of treatment shows that the treatment sites differed to non-treatment sites regardless of time period (if no interaction was found). An effect of 1080 treatment would be apparent as a significant treatment $\times$ time interaction, indicating that the change in species' relative abundance between winter 2012 and the relevant monitoring period differed between treated and non-treated sites.

\section{Study sites \\ East Coast}

In the Rolleston area, the treatment site was in the Wilberforce Valley and the non-treatment site in the Harper Valley, $19 \mathrm{~km}$ to the east. The Harper Valley has had no recent history of pest control. Both areas have forest dominated by high altitude mountain beech (Nothofagus solandri var cliffortioides), with some stands of mānuka (Leptospermum scoparium), and occasional tree fuchsia (Fuchsia excorticata). The forest understory was mainly mountain beech regeneration with some pepperwood (Pseudowintera colorata), mountain celery pine (Phyllocladus alpinus), bush lawyer (Rubus spp.) and Coprosma spp. The monitoring stations were between 620 and $1200 \mathrm{~m}$ elevation.

\section{West Coast}

In the Alexander Range, the treatment (Mt Alexander) and non-treatment (Upper Taipo River) sites were $11 \mathrm{~km}$ apart. Both sites had typical lowland/sub-alpine West Coast forest dominated by kāmahi (Weinmannia racemosa) and southern rātā (Metrosideros umbellata) with dense supplejack (Ripogonum scandens). The Upper Taipo has never been treated with aerial 1080 while Mt Alexander had been subject to aerial 1080 operations previously, most recently in 2007. The Upper Taipo has had some stoat trapping along the valley floor to protect whio (Hymenolaimus malacohrynchos). The monitoring stations were between 200 and 860 m elevation.
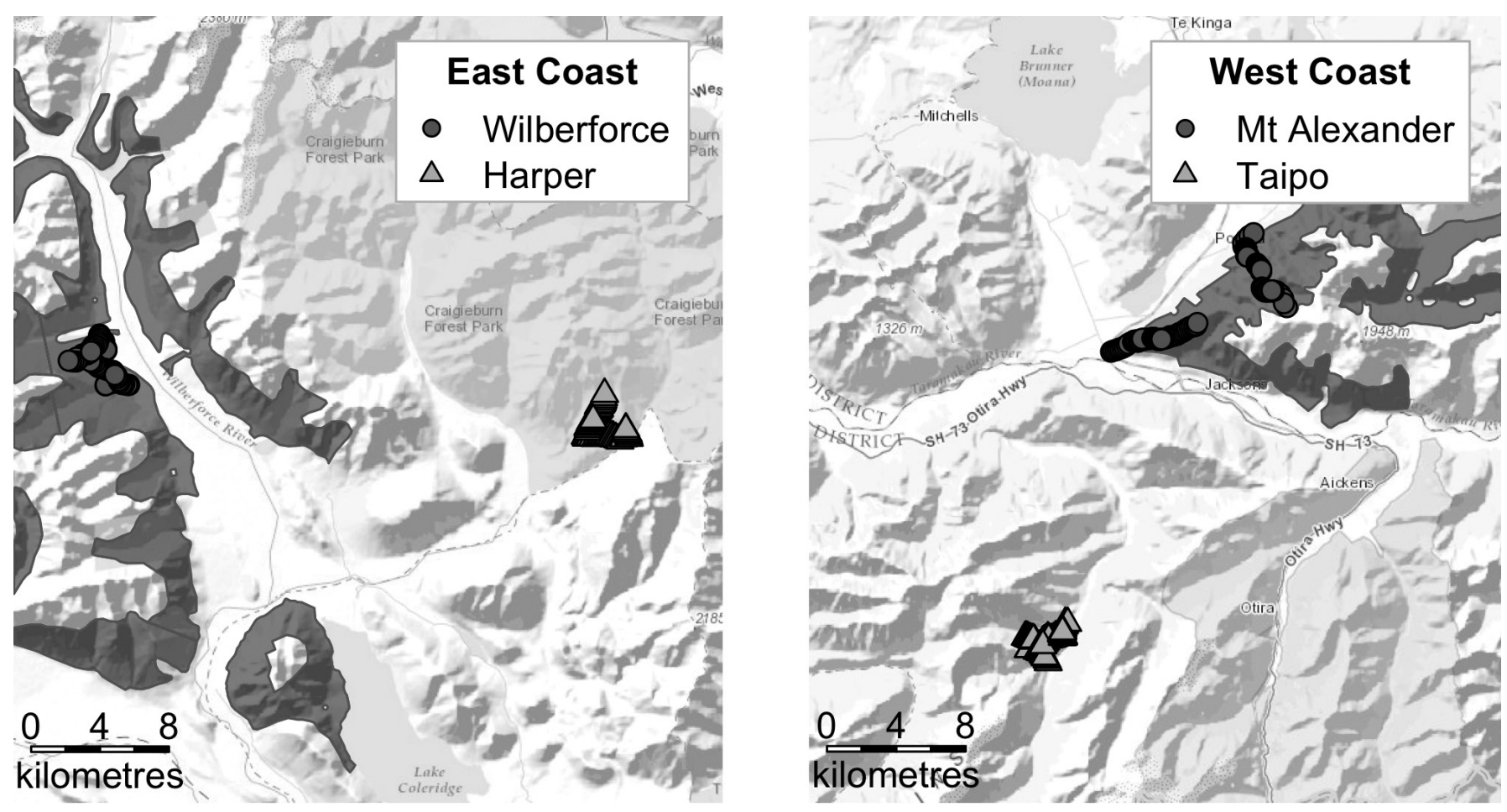

Figure 1. Location of 1080 treatment and bird monitoring lines on the Rolleston Range (East Coast) and Alexander Range (West Coast) of the South Island of New Zealand. Each point represents a bird monitoring station (purple circles in treatment sites, orange triangles in nontreatment sites). The grey-shaded polygons indicate the area treated with aerial 1080 in 2012. Map background from the R package Open Street Map: (C) OpenStreetMap contributors, CC BY-SA. 


\section{Aerial 1080}

Both treatment sites had pre-feed applications of cereal baits sown at $1 \mathrm{~kg} \mathrm{ha}^{-1}$ between 18 and 21 July 2012. Aerial 1080 was applied at a rate of $2 \mathrm{~kg} \mathrm{ha}^{-1}$ in the form of $0.15 \%$ cereal pellets containing 1.5-2.0 $\mathrm{g}$ of sodium fluoroacetate $\mathrm{kg}^{-1}$ and cinnamon lure at Rolleston on 25 July 2012 and Mt Alexander on 10 August 2012. Deer repellent was also added to the Rolleston bait. The treated areas were 23337 ha at Rolleston and 10275 ha at Alexander.

\section{Bird and mammal monitoring}

Measures of relative abundance were used for mammal monitoring and bird monitoring. Relative abundance measures are commonly used in animal monitoring, as noted in previous reviews (Engeman 2005; Lancia et al. 2005; Witmer 2005; Allen \& Engeman 2015). Valid comparisons between study periods or sites require a constant probability of detection (Ruscoe et al. 2001). In the current study, monitoring was undertaken only in good weather for hearing bird calls (avoiding periods of rain and high winds) and by experienced observers, minimising any change in detection probabilities. There is likely to have been a seasonal effect between the pre- and post-1080 periods; this potential constraint was avoided by the BACI design, which used comparisons of rates of change in relative abundance between treatments. As noted below, mammal monitoring chew cards were exposed for fewer nights than other studies have used (Burge et al. 2017). Therefore, we avoid comparisons to other mammal monitoring studies, but within-study consistency in monitoring duration allows comparison of rates of change between treatments over time.

Monitoring was undertaken before 1080 treatment (winter 2012, mid June to early August) and for the three successive summers afterwards (normally late November to early February). In each area, treatment and non-treatment sites were normally monitored within 2 weeks of each other, although in summer 2012/13 inclement weather delayed monitoring at Harper until 7 weeks after Wilberforce in early March (see Table S1 in Supplementary Material). Bird counts and mammal monitoring were conducted concurrently, sometimes extending a few days earlier or later.

\section{Mammal monitoring}

Possums, rats and mice were monitored at each site using chew cards baited with 'FeraFeed213 Special Blend' (Sweetapple $\&$ Nugent 2011). Five permanent chew card transects were established at each of the four sites, covering the same area traversed by the bird monitoring stations (Fig. 1). Each chew card transect had ten cards at $50 \mathrm{~m}$ spacing, while transects were at least $200 \mathrm{~m}$ apart. Cards were folded in half and nailed to a tree 20-30 cm above the ground. Cards were exposed for three nights, rather than the initially recommended 6-7 nights (Sweetapple \& Nugent 2011), because difficult access to the study sites made longer exposure logistically impractical. Cards were retrieved, assessed and scored by experienced observers with the aid of reference material. Possum and rodent indices of relative abundance were calculated as the mean proportion of cards chewed per transect.

\section{Bird monitoring}

Relative abundance of bird species was assessed using the point count method, which is consistent with the decisionmaking framework in Veltman et al. (2014) given that banding birds was not suitable for the scale of this experiment. In each study area, two transects were established for monitoring birds. Each transect consisted of ten permanent bird counting stations spaced at $200 \mathrm{~m}$ intervals. At Mt Alexander in the first monitoring period (winter 2012) we used a single transect of ten stations at $200 \mathrm{~m}$ spacing located at Inchbonnie. In subsequent summers, four to 10 additional stations were counted on this same line as the extra daylight allowed. We added an extra transect of 10 stations at Camp Creek for the last two monitoring periods (summer 2013/14 and summer 2014/15). We ran all bird analyses with and without the additional Inchbonnie stations and found no differences in the significance of season by 1080 treatment for all bird species, and therefore we retained the full dataset and report results with all counted stations included. All transect lines followed ridges, except the lower section of the Camp Creek transect which was near the creek.

Each bird transect was normally traversed twice daily for 4 consecutive days during each sampling period. Two experienced observers were used in any given sampling period, with observers normally alternating daily between the two transects at each site. Five-minute bird counts were conducted as in Dawson and Bull (1975), identifying all birds to species level, whether seen or heard. A few birds not identified to species level(260 of 19134 records) were excluded from our analyses. Estimates of distance from observers were not recorded, as estimating the distance of calling birds accurately is difficult (Nadeau \& Conway 2012). Bird counts were conducted no earlier than one hour after sunrise and no later than one hour before sunset, and not during rain or high winds. Transects were generally walked between 0830 and 1500 hours when the birds are most conspicuous.

\section{Data analysis}

We used generalised linear mixed effects models (GLMMs) to examine the effects of 1080 on the three mammal species and the nine most common bird species. We analysed both West and East Coast sites together to test for general, rather than local, effects of 1080 (except for mice and rats as explained below). Except where specified, we analysed the effect of treatment (treated or not treated with 1080) and time (a factor with four levels: pre-treatment, and the three summers following treatment) on mammal and bird abundance, and report on differences arising over time in 1080-treated sites compared to non-treatment sites (i.e. the interaction between time and treatment, normally using the pre-treatment winter 2012 counts as the baseline). The random effects varied to suit each analysis (see below). All models were implemented using the statistical software package $\mathrm{R}$ version 3.3.1 (R Core Team 2016) and unless otherwise noted, package lme4 (Bates et al. 2015).

We tested for and found no significant differences in winter 2012 (pre-treatment) possum abundance between the East and West Coast sites $(\mathrm{p}=0.26$, analysis not shown). Following 1080 treatment, we detected no possums or rodents at treatment sites during some monitoring periods. This led to complete separation of the data, and limited what could be tested statistically. In each model, the mammal response variable specified was the number of cards marked per transect of the relevant species as a proportion of the total in the transect (in this study, always 10). These models used a binomial error distribution. 


\section{Possums}

Following 1080 treatment, possums were reduced to such low indices of relative abundance that none were detected at the West Coast site (Mt Alexander) for the remainder of the study. This restricted the analysis for possums to three more specific questions on subsets of the data.

1. Did the paired treatment and non-treatment sites differ in relative possum abundance prior to 1080 treatment? Paired sites on each coast were modelled separately with site as a fixed effect, and a random intercept of transect nested within site. Data only included the pre-1080 (winter 2012) monitoring period, and we report whether there were significant differences between sites, for each coast.

2. As possums re-established to detectable levels on the East Coast (Wilberforce), how did their relative abundance compare to the untreated site (Harper)? One monitoring period (summer 2012/13) had to be excluded from this analysis because of complete separation. Therefore, the model included only the East Coast sites for winter 2012, summer 2013/14 and summer 2014/15. The model included effects of site and monitoring period, and the interaction between them. A random intercept of transect nested within site was included. This model was over-dispersed, so an individual-level random effect was also included. We report on whether sites differed over time following 1080 (i.e. the interaction between site and time).

3. How did relative possum abundance vary in untreated sites over the course of the study duration? We included only data from untreated sites in this analysis, but included all monitoring periods. We tested the East and West Coasts separately, with season as a fixed effect and a random intercept for each transect. As there is no 1080 effect expected in non-treatment sites, we compared the summer 2012/13 period to all other monitoring periods to minimise season effects.

\section{Mice}

Mice appeared to respond to a beech mast year during 2013/14 on the East Coast (no beech Nothofagus spp. were present in the West Coast sites), and therefore, for mice the two areas were analysed separately. Although some sites had very low relative mouse abundance, we were able to model all time periods by adding a small uninformative Bayesian fixed effects prior using package blme in R (Chung et al. 2013). For each coast, we specified fixed effects of monitoring period and treatment, and an interaction between the two. Mouse models converged only with a simple random intercept of transect. We report on how mice numbers differed over time between winter 2012, and the monitoring periods following 1080 treatment (i.e. the interaction between treatment and season).

\section{Rats}

Rats were only present on the West Coast; however, in the non-treatment site (Taipo) they were near absent for the first two monitoring periods. We compared rat indices of relative abundance at the treated site during summer 2012, to the winter prior and subsequent summers. We used a fixed effect of season with a random intercept for each transect. This model was over-dispersed and an observation-level intercept was added as part of the random effects to counter the overdispersion.

\section{Birds}

We analysed relative abundance of the nine most common bird species, using GLMMs with a Poisson error distribution. The most common birds were bellbird (Anthornis melanura, $\mathrm{n}=$ 3671 recorded over all sites and years), silvereye (Zosterops lateralis, 3271), tomtit (1913), rifleman (Acanthisitta chloris, 1893), chaffinch (Fringilla colelebs, 1741), brown creeper (Mohoua novaeseelandiae, 1557), grey warbler (Gerygone igata, 1433), blackbird (Turdus merula, 855) and fantail (Rhipidura fuliginosa, 554). The next most-common species were tūī (Prosthemadera novaeseeladiae, 345) and redpoll (Carduelis flammea, 333); neither averaged more than 0.4 recordings per bird count during the entire monitoring period (see Table S7 in Supplementary Material).

The response variable was the daily total count of a species at each station, with an offset (log-transformed) for the number of five-minute counts at that station that day (range one to four). Our models incorporated random effects to account for repeated counts at stations and the nested nature of the experimental design. We specified a random intercept of bird monitoring station nested within transect nested within site nested within area. Where models were overdispersed (bellbird, brown creeper, chaffinch, grey warbler, rifleman and silvereye), an individual observation level random effect was added, as for mammals. One observer used in monitoring during winter 2012 had reduced ability to hear the high-pitched calls of riflemen, so we added an additional random effect to the rifleman model, nested within the intercept term for station, which was the number of counts (as a factor) undertaken in that day by that observer.

\section{Correlation between mammals and birds}

To test directly for an effect of mammal abundance on bird counts, we used data only for possums in the non-treatment sites. Possums in treatment sites had almost no variation in possum abundance following 1080 treatment (always near zero) so gave little information about effects on birds. Similarly, rats had too little observed variation in abundance. We did not analyse mice, because there is no evidence they have any direct effect on any of the bird species considered here (Innes et al. 2010). To test the effect of possum densities in non-treatment areas on changes in bird counts, we implemented a mixed effects model with a Gaussian distribution using package nlme (Pinheiro et al. 2016). The predictor was the possum chew-card index at one survey, while the response variable was the change in bird counts between then and the following survey. A replicate was the change in one bird species, at one of the sites, between two consecutive monitoring periods. The change in bird counts, for all bird species, was calculated as $\mathrm{S} 2 /(\mathrm{S} 1+\mathrm{S} 2)$, where $\mathrm{S} 1$ and $\mathrm{S} 2$ are counts at time 1 and time 2 respectively. This ratio takes a value $>0.5$ if the bird species increased, and $<0.5$ if it decreased, over the interval. The GLMM included a random intercept for each bird species, and a random intercept for each area. We compared linear and quadratic terms using model selection (Burnham \& Anderson 2002) using R package MuMIn (Bartoń 2016).

\section{Results}

\section{Possums}

Possums showed strong effects of 1080 (Fig. 2). Prior to 1080 treatment, possum abundance did not differ between 

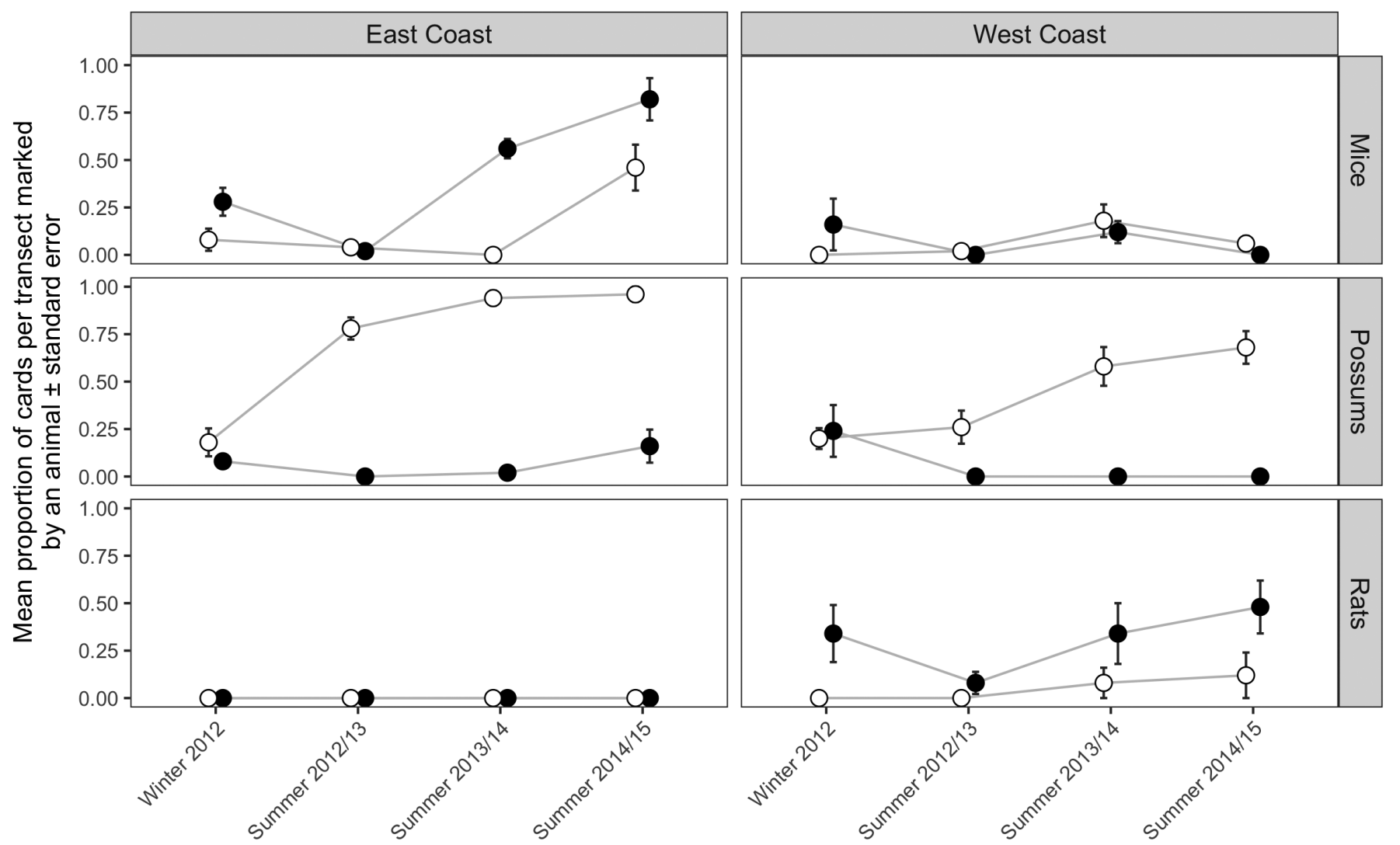

Measurement period

1080 treatment $\bigcirc$ No 1080

1080 applied

Figure 2. Relative abundance of three mammal pest species (mean \pm SEM) determined through chew card surveys before and after 1080 treatment (applied after the first survey).

treatment and non-treatment sites on either the East Coast $(\mathrm{z}=-1.33, \mathrm{p}=0.184)$ or West Coast $(\mathrm{z}=-0.04, \mathrm{p}=0.968)$. Possum detections decreased in 1080-treated areas from $16 \%$ (percentage of cards interfered with per transect) in the winter of 2012 to less than $1 \%$ in the first two monitoring periods post-1080 and to $8 \%$ in the third season (Fig. 2). The complete separation (discussed in Methods) limited statistical analysis, but on the East Coast, relative possum abundance decreased from winter 2012 to summer 2013/14 ( $z=-3.987, p<0.001)$ and to summer $2014 / 15(\mathrm{z}=-3.349, \mathrm{p}<0.001)$ in treatment sites compared to non-treatment sites. In non-treatment sites, we compared the summer 2012/13 monitoring period to the previous winter and following summers to minimise seasonal effects. Possum detections in non-treatment sites increased on the East Coast between the winter of 2012 and summer of 2012/13 ( $z=-5.454, p=<0.001)$, while in that period on the West Coast possum detections did not change $(\mathrm{z}=-0.717, \mathrm{p}=0.47)$. Possums increased each year thereafter at both non-treatment sites (East Coast, summer 2013/14: $\mathrm{z}=$ 2.186, $\mathrm{p}=0.029$; East Coast, summer 2014/15: $\mathrm{z}=2.419, \mathrm{p}$ $=0.016$; West Coast, summer 2013/14: $\mathrm{z}=3.196, \mathrm{p}=0.001$; West Coast, summer 2014/15: $\mathrm{z}=4.086, \mathrm{p}<0.001)$. Overall, in sites treated with 1080 possums decreased and were slow to recover, whereas in non-treatment sites they increased throughout the study. Full details of the possum analysis are given in Tables S2-S4 in Supplementary Material.

\section{Mice}

Changes in mouse abundance were analysed separately for East and West Coast sites because of the influence of beech mast seeding on the East Coast (Fig. 2). Mice were initially low on the East Coast, and showed no significant difference in trend between non-treatment and treatment sites to the first summer following 1080 treatment $(z=-1.622, p=0.105)$. By the second year post-1080, mouse abundance had increased significantly more in the treatment site than the non-treatment site $(z=2.921, p=0.004)$. There were no differences between treated and untreated sites in the change from winter 2012 to the summer of $2014 / 15(z=0.421, p=0.674)$, because mice increased similarly at both. On the West Coast, mouse abundance was low in both the non-treatment and treatment sites and never exceeded $20 \%$ across the study duration (Fig. 2). In this area, differences between treatment and nontreatment sites in mouse abundance compared to winter 2012 were only significant in the 2014/2015 summer $(z=-2.104$, $\mathrm{p}=0.035)$. Overall, mice showed little change attributable to 1080 treatment, but did increase significantly on the East Coast at both sites after the beech mast seeding event. The mouse analysis is listed in full in Table S5 in Supplementary Material.

\section{Rats}

Rats were only detected on the West Coast sites, but they were absent from the non-treatment site for the first two periods (Fig. 
2), making complete statistical comparisons to the 1080-treated sites impossible. Therefore, we report changes in relative rat abundance in the 1080-treated site in winter 2012, summer 2013/14 and summer 2014/15 compared to summer 2012/13 to minimise seasonal effects. Relative rat abundance was higher in winter 2012 preceding the 1080 drop compared to summer $2012 / 13(z=2.21, p=0.027)$, but increased in both $2013 / 14$ $(\mathrm{z}=2.108, \mathrm{p}=0.035)$ and $2014 / 2015(\mathrm{z}=2.902, \mathrm{p}=0.004)$ to levels similar to those pre-1080 treatment. Overall, rats were absent in the east, and in the west showed a significant, but short-lived, decrease in relative abundance. Full details of the rat analysis can be found in Table S6 in Supplementary Material.

\section{Birds}

Over the course of the study 1940 five-minute bird counts were conducted across all sites. Of the 33 bird species recorded, 19 were native and 14 introduced (Table S7). The key test for 1080 impact was a significant time $\times$ treatment interaction from winter 2012 until each later sampling date (see Methods). In the summer following 1080 treatment, none of the nine tested bird species declined significantly more at treatment than non-treatment sites (Fig. 3), indicating a lack of acute toxic effects. On the contrary, in the season following 1080 treatment three species (tomtit, silvereye, grey warbler) increased in treatment sites more than non-treatment sites (see Table S8 in Supplementary Material). We found a significant negative interaction for blackbirds, which increased in treatment sites, but less so than at non-treatment sites. Bellbirds showed no significant effect in the first summer following 1080 treatment, but increased significantly in treatment areas to triple their pre-1080 numbers by the final season of monitoring (2014/15). Silvereyes had a slightly lower abundance at treatment sites prior to 1080 treatment, but increased afterwards to higher levels in treatment sites, significantly so in the summers 2012/13 and $2014 / 15$. Tomtits increased more in treatment areas than nontreatment areas in all three post- 1080 monitoring periods. It was only in the third summer following 1080 treatment (2014/15) that we observed any significant declines at treatment, compared to non-treatment sites, for blackbirds, chaffinch and riflemen. Full plots of all the coefficients, including interactions, for each bird species are in the Supplementary Material (Figure S1).

\section{Correlation between mammals and birds}

Higher possum abundance in the untreated sites correlated with declines in bird abundance over the subsequent interval (Fig. 4). A linear model gave the best fit; although a quadratic model was not much worse when assessed with AICc ( $\triangle \mathrm{AICc}$ $=1.31)$, here we present the simpler linear model. In the linear model, lagged possum abundance was significantly negatively correlated with changes in bird abundance $(\mathrm{t}=-5.211, \mathrm{p}<$ 0.001 ), indicating that higher possum chew-card indices were associated with declines in birds over the subsequent interval.
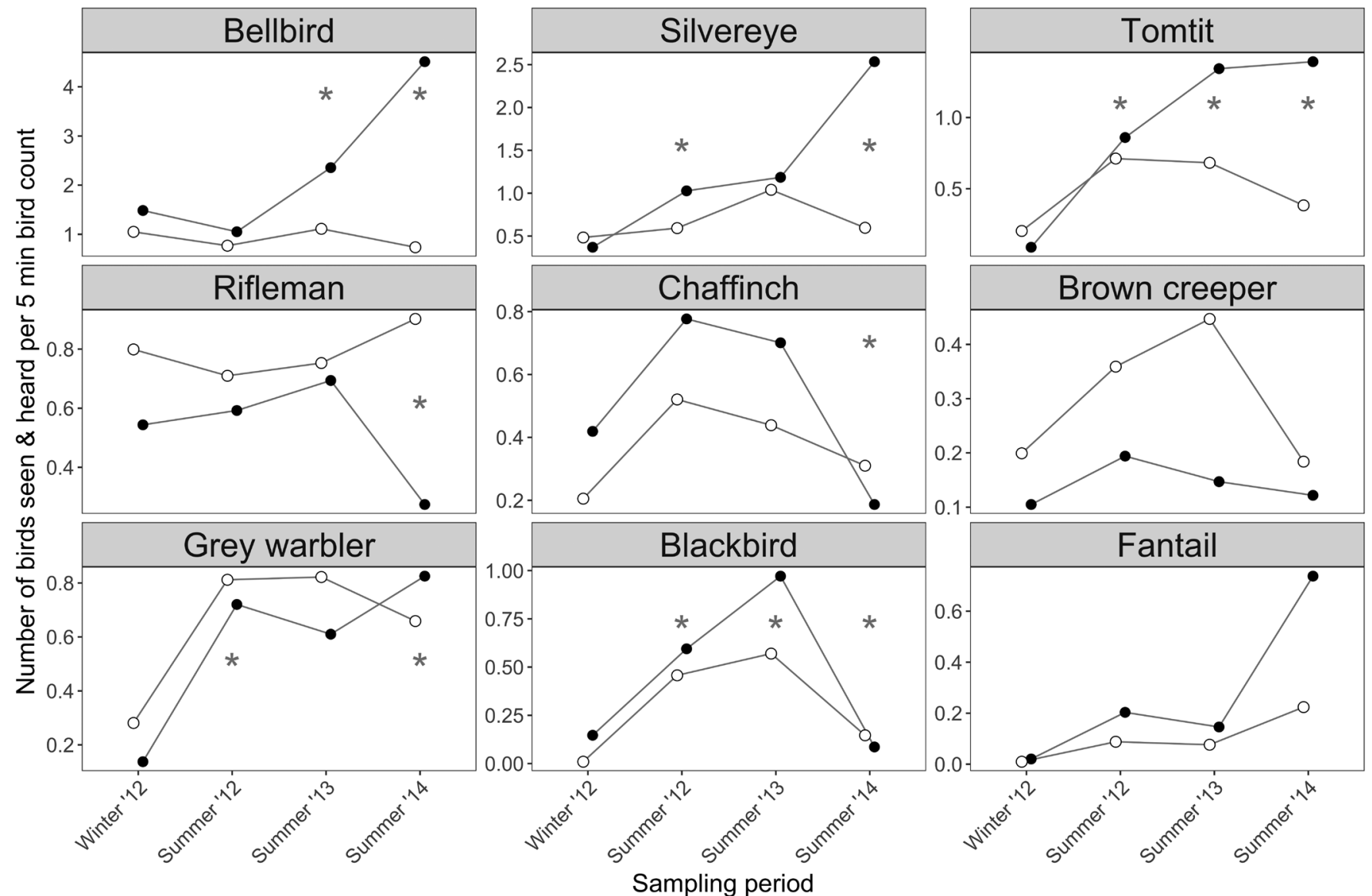

\section{0 treatment $\circ$ No $1080 \bullet 1080$ applied}

Figure 3. Changes in five-minute bird counts (East and West Coast areas combined) for the nine most common species. Asterisks indicate a significant 1080 effect, tested with the time $\times$ treatment interaction in GLMMs (i.e. a difference between treatment and non-treatment areas in the changes in relative abundance between winter 2012 and each subsequent monitoring period), for details see Table S8. Note $\mathrm{y}$-axis scales differ between panels. 


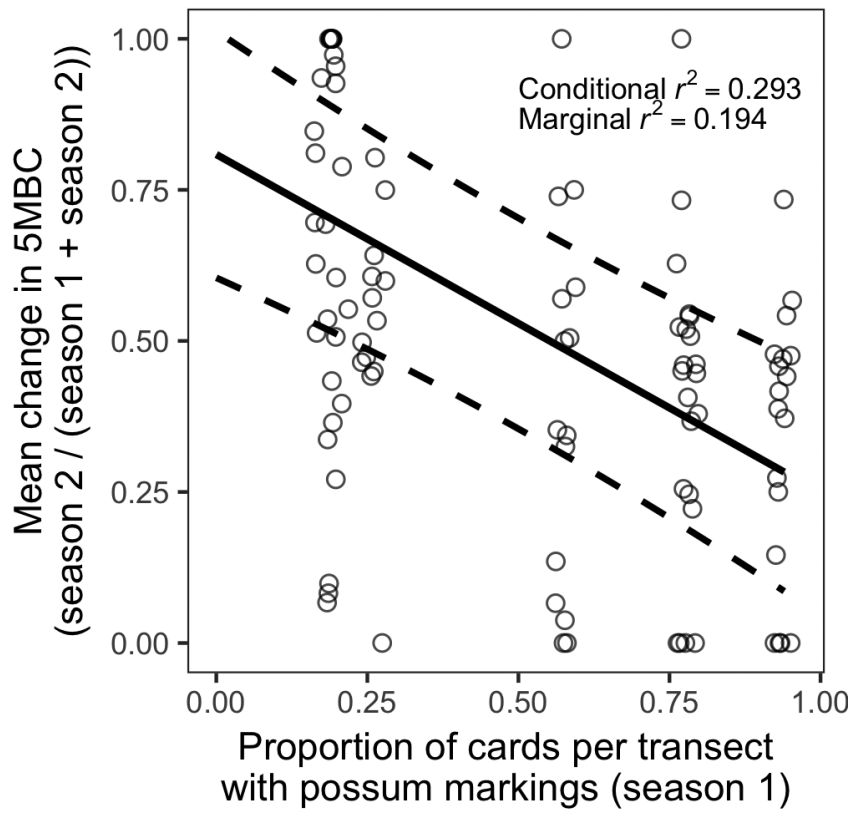

Figure 4. The relationship between relative possum abundance at a sample time (proportion of chew cards marked) and changes in relative abundance of birds per 5-minute count (5MBC) over the subsequent interval. Each point represents an individual bird species over one interval at one site; only the two non-treatment sites are included. Jitter has been added to make overlapping points visible. $\mathrm{Y}$ axis values $>0.5$ represent increases in bird abundance; $<0.5$ represent decreases. The fitted line is shown with $95 \%$ confidence intervals (dashed lines).

The model was a relatively good fit to the data: marginal $\mathrm{R}^{2}$ (variance explained by fixed effects alone) was 0.194 , while conditional $\mathrm{R}^{2}$ (variance explained by both fixed and random effects) was 0.293 . The effect size is quite large when backtransformed to a percentage increase or decrease: for low possum abundances ( $\sim 0.2$ proportion chew cards marked) the fitted value is for birds on average to increase from one year to the next by $\sim 50 \%$ (back-transformed from y-axis value of $0.6)$, whereas under high possum abundances ( $\sim 0.9$ proportion marked) birds decreased on average by about $50 \%$ the following year (back-transformed from y-axis value of 0.3 ).

\section{Discussion}

Overall, no acute effects of 1080 were seen at the population level for common native bird species. 1080 was effective at depressing relative possum abundance for 2-4 years, but was effective only in the short-term for rat species. Possums were reduced to non-detectable levels in the summer following 1080 treatment and remained low in treated areas for 2 years thereafter. This is consistent with previous work showing that 1080 treatment can effectively reduce possum numbers, and population recovery may take up to 5-6 years (Nugent et al. 2010). In untreated areas, the relative abundance of possums more than doubled over the course of the study. This result was unexpected as neither non-treatment site had a prior history of large-scale possum control, so could reasonably be expected to be at equilibrium. Reasons for the increase are not known; weather was cold on the East Coast in winter 2012 when sampling with snow on the ground, which might have reduced possum activity or subsequent overwinter survival, but this did not apply on the West Coast.

Mouse abundance showed no changes attributable to 1080 , but at the East Coast sites increased during or after a major beech mast seeding event which occurred in autumn 2014. Mice are known to start increasing during summer beech flowering, by feeding on the caterpillars which eat beech flowers (Fitzgerald et al. 2004; Kelly et al. 2008) and this finding is consistent with mice having increased at the treatment site in summer 2013/14 before seedfall occurred. It is not known why mice at the non-treatment site did not increase until a year later, by summer $2014 / 15$. Previously a study at Craigieburn (5 $\mathrm{km}$ east of the Harper site) found that stoat trapping resulted in an increase in the mouse population (Kelly et al. 2005). It is possible that a reduction in stoat densities following 1080 treatment (from secondary poisoning) reduced predation on mice and therefore allowed a more rapid increase in mouse relative abundance during the mast event in the treatment area than in the adjacent non-treatment area.

Rats were absent on the East Coast and this did not change either after 1080 treatment or after mast seeding. On the West Coast, rats followed the expected pattern of a significant decrease after 1080 treatment with a rapid recovery the following year (Holdaway 1989; Innes et al. 1995; Gillies \& Pierce 1999; Murphy et al. 1999; Alterio 2000; Dowding \& Murphy 2001; Speedy 2005; Gibbs 2009). In the North Island, rats increased when possum densities were suppressed, most likely due to competition for food between possums and rats (Ruscoe et al. 2011). We found no evidence for this 'competitive release' or for any meso-predator release after secondary poisoning of stoats, because rat numbers at the treatment site (MtAlexander) returned to about the same level they were at pre-treatment, despite possum numbers being lower post-1080 than pre-1080 treatment.

For native forest birds, we found no significant immediate negative impacts of 1080 across the two forest systems we examined. We found a negative interaction for blackbirds, which increased after 1080, but less so than at non-treatment sites. The only other immediate effects were positive, for three species (silvereye, tomtit and grey warbler). The increases in silvereyes and grey warblers were unexpected as both species are common in towns and modified habitats which might suggest they are less susceptible to introduced predators (Innes et al.2010). Historically, tomtits have suffered mortality in 1080 operations (Lloyd \& McQueen 2000; Powlesland et al. 2000), but changes to bait type, bait size distributions, repellents, and sowing rates are considered to have greatly reduced these nontarget impacts (Westbrooke \& Powlesland 2005; Clapperton et al. 2014). Our results support recent studies which found the direct negative effects on tomtits to be small (Westbrooke et al. 2003; Westbrooke \& Powlesland 2005) or absent (Greene et al. 2013). Moreover, we found large increases in tomtit abundance as a result of one-off 1080 operations, with the size of the increase second only to bellbirds, and increases in relative abundance sustained through every post-treatment summer. The benefits to birds of 1080 treatment are presumably due to lower numbers of mammals, including possums, rats, and (by secondary poisoning) stoats.

Some other bird species also showed multi-year differences in trends between treatment and non-treatment sites. Because of the increasing time lag post-treatment, these can be less certainly ascribed to 1080 effects, even though our use of two independent sites reduces the risk of confounding effects. Bellbirds showed no significant difference in the first summer, 
but then increased at treatment sites relative to the non-treatment ones for the following two summers. It is possible the bellbird increase is due to a delayed (relative) benefit of pest control, as during that time possum densities continued to increase in the non-treatment sites. However, at Craigieburn (near the Rolleston sites), Kelly et al. (2005) found no evidence of predation on bellbird nests by possums, and bellbird densities increased rapidly (79\% in the first season) following stoat trapping. At another site, Maungatautari Sanctuary (central North Island), the increase in bellbirds was delayed; after eradication of all pests in 2007 bellbirds did not increase until 2010 (Iles \& Kelly 2014). If the bellbird increase was due to lower possum abundance it may have partly been from reduced food competition, since possums and bellbirds both eat large invertebrates, fruit and flowers/nectar. Changes in abundance only in the final year (2014/15 season), including decreases in riflemen, chaffinches and blackbirds, are unlikely to be attributable to a delayed effect of 1080 treatment so are not considered further.

Short to medium-term benefits to birds would be expected from mammalian pest control. We found that in the nontreatment areas, lower possum densities were correlated with increases in bird detections per five-minute count when averaged across all bird species. This result is consistent with work showing possums as important predators of birds (Brown et al. 1993; Owen \& Norton 1995; Cowan 2001), giving added confidence that in the treatment sites the low possum densities resulting from 1080 would benefit birds locally. Separately, in treatment areas where rats were present, we found rat abundance decreased significantly in the first summer post-1080, which would also be expected to provide a short-lived benefit to birds. We have no data on stoat abundance, but secondary poisoning should have also reduced stoat abundance post-1080.

\section{Conclusions}

Reviews have found that aerially applied 1080 is one of the safest and most cost-effective tools for conservation management (Wright 2011); however, there has been a lack of detailed longer-term monitoring of common bird species. By monitoring the effects of 1080 over 4 years, and replicating our experiment across two different forest types using a BACI design, we found that one-off aerial 1080 operations for bovine Tb delivered conservation benefits even for common forest bird species, some of which are continuing to decline elsewhere (Elliott et al. 2010; Innes et al. 2010). We found long-lasting decreases in possum abundance, and a one-year drop in rat abundance. There was no subsequent 'competitor-release' overshoot in rat abundance. Short-term effects on forest birds were all positive or neutral; longer-term effects on native birds were largely positive or neutral. Finally, analysis of data from our non-treatment areas found higher possum abundance was correlated with declines across the range of bird species. Overall, this replicated long-term study found that for common forest birds there were some apparent conservation benefits, and no apparent conservation drawbacks, from aerially applied 1080 for possum control.

\section{Data availability}

The data associated with the paper is available from the Landcare Research data repository at

https://doi.org/10.7931/J2ZW1J3R

\section{Acknowledgements}

We thank all those who helped with field work (Alwin Sky, Tim Galloway, Amanda Peterson, Kelly Whitau, and James Mortimer), Jenny Ladley and Kim Roberts for peerless logistic support, and Glenthorne Station for access and accommodation at Rolleston. This work was funded by the Animal Health Board (now OSPRI), but they placed no constraints on publication of the data.

\section{References}

Allen LR, Engeman RM 2015. Evaluating and validating abundance monitoring methods in the absence of populations of known size: review and application to a passive tracking index. Environmental Science and Pollution Research International 22: 2907-2915.

Alterio N 2000. Controlling small mammal predators using sodium monofluoroacetate (1080) in bait stations along forestry roads in a New Zealand beech forest. New Zealand Journal of Ecology 24: 3-9.

Bartoń K 2016. MuMIn: multi-model inference. R package version 1.15.6. https://cran.r-project.org/package=MuMIn.

Bates D, Maechler M, Bolker B, Walker S 2015. Fitting linear mixed-effects models using lme4. Journal of Statistical Software 67: 1-48.

Booth LH, Wickstrom ML 1999. The toxicity of sodium monofluoroacetate(1080) to Huberia striata, a New Zealand native ant. New Zealand Journal of Ecology 23: 161-165.

Brown K, Innes J, Shorten R 1993. Evidence that possums prey on and scavenge birds' eggs, birds and mammals. Notornis 40: 169-177.

Burge OR, Kelly D, Wilmshurst JM 2017. Interspecies interference and monitoring duration affect detection rates in chew cards. Austral Ecology 42: 522-532.

Burnham KP, Anderson DR 2002. Model selection and multimodel inference: a practical information-theoretic approach. New York, Springer Verlag. 488 p.

Chung Y, Rabe-Hesketh S, Dorie V, Gelman A, Liu J 2013. A nondegenerate penalized likelihood estimator for variance parameters in multilevel models. Psychometrika 78: 685-709.

Clapperton BK, Morgan DKJ, Day TD, Oates KE, Beath AM, Cox NR, Matthews LR 2014. Efficacy of bird repellents at deterring north island robins (Petroica australis longipes) and tomtits (P. macrocephala toitoi) from baits. New Zealand Journal of Ecology 38: 116-123.

Cowan PE 2001. Advances in New Zealand mammalogy 1990-2000: brushtail possum. Journal of the Royal Society of New Zealand 31: 15-29.

Craig J, Anderson S, Clout M, Creese B, Mitchell N, Ogden J, Roberts M, Ussher G 2000. Conservation issues in New Zealand. Annual Review of Ecology and Systematics 31: 61-78.

Dawson DG, Bull PC 1975. Counting birds in New Zealand forests. Notornis 22: 101-109.

Dowding JE, Murphy EC 2001. The impact of predation by introduced mammals on endemic shorebirds in New Zealand: a conservation perspective. Biological Conservation 99: 47-64.

Elliott G, Kemp J 2016. Large-scale pest control in New Zealand beech forests. Ecological Management \& Restoration 17: 200-209. 
Elliott GP, Wilson PR, Taylor RH, Beggs JR 2010. Declines in common, widespread native birds in a mature temperate forest. Biological Conservation 143: 2119-2126.

Engeman RM2005. Indexing principles and a widely applicable paradigm for indexing animal populations. Wildlife Research 32: 203-210.

ERMA 2007. Animal Health Board (AHB) and Department of Conservation (DoC)-reassessment of sodium fluoroacetate (1080) and formulated substances containing 1080 (a vertebrate toxin) by a committee of the Environmental Risk Management Authority. HRE05002.

Fitzgerald B, Efford M, Karl B 2004. Breeding of house mice and the mast seeding of southern beeches in the Orongorongo Valley, New Zealand. New Zealand Journal of Zoology 31: 167-184.

Gibbs GW 2009. The end of an 80-million year experiment: a review of evidence describing the impact of introduced rodents on New Zealand's 'mammal-free' invertebrate fauna. Biological Invasions 11: 1587-1593.

Gillies CA, Pierce RJ 1999. Secondary poisoning of mammalian predators during possum and rodent control operations at Trounson Kauri Park, Northland, New Zealand. New Zealand Journal of Ecology 23: 183-192.

Gillies CA, Leach MR, Coad NB, Theobald SW, Campbell J, Herbert T, Graham PJ, Pierce RJ 2003. Six years of intensive pest mammal control at Trounson Kauri Park, a Department of Conservation "mainland island", June 1996-July 2002. New Zealand Journal of Zoology 30: $399-420$.

Greene TC, Dilks PJ, Westbrooke IM, Pryde MA 2013. Monitoring selected forest bird species through aerial application of 1080 baits, Waitutu, New Zealand. New Zealand Journal of Ecology 37: 41-50.

Holdaway RN 1989. New Zealand's pre-human avifauna and its vulnerability. New Zealand Journal of Ecology 12: 11-25.

Iles JM, Kelly D 2014. Restoring bird pollination of Fuchsia excorticata by mammalian predator control. New Zealand Journal of Ecology 38: 297-306.

Innes J, Warburton B, Williams D, Speed H, Bradfield P 1995. Large-scale poisoning of ship rats (Rattus rattus) in indigenous forests of the North Island, New Zealand. New Zealand Journal of Ecology 19: 5-17.

Innes J, Kelly D, Overton JM, Gillies C 2010. Predation and other factors currently limiting New Zealand forest birds. New Zealand Journal of Ecology 34: 86-114.

Kelly D, Brindle C, Ladley JJ, Robertson AW, Maddigan FW, Butler J, Ward-Smith T, Murphy DJ, Sessions LA 2005. Can stoat (Mustela erminea) trapping increase bellbird (Anthornis melanura) populations and benefit mistletoe (Peraxilla tetrapetala) pollination? New Zealand Journal of Ecology 29: 69-82.

Kelly D, Koenig WD, LiebholdAM 2008. An intercontinental comparison of the dynamic behavior of mast seeding communities. Population Ecology 50: 329-342.

Lancia RA, Kendall WL, Pollock KH, Nichols JD 2005. Estimating the number of animals in wildlife populations. In: Braun $\mathrm{C}$ ed. Techniques for wildlife investigations and management. Bethesda, MD, USA, Wildlife Society. Pp. 106-153.

Lloyd B, McQueen S 2000. An assessment of the probability of secondary poisoning of forest insectivores following an aerial 1080 possum control operation. New Zealand Journal of Ecology 24: 47-56.

Moorhouse R, Greene T, Dilks P, Powlesland R, Moran L,
Taylor G, Jones A, Knegtmans J, Wills D, Pryde M, Fraser I, August A, August C 2003. Control of introduced mammalian predators improves kaka Nestor meridionalis breeding success: reversing the decline of a threatened New Zealand parrot. Biological Conservation 110:33-44.

Murphy EC, Robbins L, Young JB, Dowding JE 1999. Secondary poisoning of stoats after an aerial 1080 poison operation in Pureora Forest, New Zealand. New Zealand Journal of Ecology 23: 175-182.

Nadeau CP, Conway CJ 2012. Field evaluation of distanceestimation error during wetland-dependent bird surveys. Wildlife Research 39: 311-320.

Nugent G, Whitford J, Sweetapple P, Duncan R, Holland P 2010. Effect of one-hit control on the density of possums (Trichosurus vulpecula) and their impacts on native forest. Wellington, New Zealand, Department of Conservation. $64 \mathrm{p}$.

O’Donnell CFJ, Hoare JM 2012. Quantifying the benefits of long-term integrated pest control for forest bird populations in a New Zealand temperate rainforest. New Zealand Journal of Ecology 36: 131-140.

O’Halloran K, Jones D, Booth L, Fisher P2005. Ecotoxicity of sodium fluoroacetate (compound 1080) to soil organisms. Environmental Toxicology and Chemistry 24: 1211-1218.

Owen HJ, Norton DA 1995. The diet of introduced brushtail possums Trichosurus vulpecula in a low-diversity New Zealand Nothofagus forest and possible implications for conservation management. Biological Conservation 71: 339-345.

Pinheiro J, Bates D, Debroy S, Sarkar D, R Core Team 2016. nlme: linear and nonlinear mixed effects models. R package version 3.1-125. http://cran.r-project.org/package=nlme.

Powlesland R, Knegtmans J, Marshall I 1999. Costs and benefits of aerial 1080 possum control operations using carrot baits to North Island robins (Petroica australis longipes), Pureora Forest Park. New Zealand Journal of Ecology 23: 149-159.

Powlesland RG, Knegtmans JW, Styche A 2000. Mortality of North Island tomtits (Petroica macrocephala toitoi) caused by aerial 1080 possum control operations, 199798, Pureora Forest Park. New Zealand Journal of Ecology 24: 161-168.

Powlesland RG, Wills DE, August ACL, August CK 2003. Effects of a 1080 operation on kaka and kereru survival and nesting success, Whirinaki Forest Park. New Zealand Journal of Ecology 27: 125-137.

R Core Team 2016. R: a language and environment for statistical computing. R Foundation for Statistical Computing, Vienna, Austria. www.r-project.org.

Robertson HA, Colbourne RM, Graham P, Miller PJ, Pierce RJ 1999. Survival of brown kiwi exposed to 1080 poison used for control of brushtail possums in Northland, New Zealand. Wildlife Research 26: 209-214.

Ruscoe WA, Goldsmith R, Choquenot D 2001. A comparison of population estimates and abundance indices for house mice inhabiting beech forests in New Zealand. Wildlife Research 28: 173-178.

Ruscoe WA, Ramsey DSL, Pech RP, Sweetapple PJ, Yockney I, Barron MC, Perry M, Nugent G, Carran R, Warne R, Brausch C, Duncan RP2011. Unexpected consequences of control: competitive vs. predator release in a four-species assemblage of invasive mammals. Ecology Letters 14: 1035-1042.

Schadewinkel RB, Senior AM, Wilson DJ, Jamieson IG 2014. 
Effects on South Island robins (Petroica australis) from pest control using aerially applied 1080 poison. New Zealand Journal of Ecology 38: 315-321.

Smith ANH, Westbrooke IM 2004. Changes in bird conspicuousness at Pureora Forest. Notornis 51: 21-25.

Speedy C 2005. Field trials and operational results of a deer repellent for 1080 possum baits. New Zealand Journal of Forestry 50: 27-30.

SurenAM, Bonnett ML 2006. Consumption of baits containing sodium fluoroacetate (1080) by the New Zealand freshwater crayfish (Paranephrops planifrons). New Zealand Journal of Marine and Freshwater Research 40: 169-178.

Suren AM, Lambert P 2006. Do toxic baits containing sodium fluroacetate (1080) affect fish and invertebrate communities when they fall into streams? New Zealand Journal of Marine and Freshwater Research 40: 531-546.

Sweetapple P, Nugent G 2011. Chew-track-cards: a multiplespecies small mammal detection device. New Zealand Journal of Ecology 35: 153-162.

van Klink P, Kemp J, O'Donnell CFJ 2013. The effect of aerial application of 1080 cereal baits on radio-tagged South Island fernbirds (Bowdleria punctata punctata). New Zealand Journal of Zoology 40: 145-153.

Editorial board member: Jo Monks

Received 12 January 2017; accepted 12 January 2018

\section{Supplementary Material}

Additional supporting information may be found in the online version of this article:

Table S1. Start dates for mammal monitoring at each site, using chew cards exposed for three nights.

Table S2. Generalised linear mixed effect output of models testing whether sites on the East and West Coasts varied in relative possum abundance prior to 1080 application.

Table S3. Generalised linear mixed effect output of model testing whether relative possum abundance on the East Coast differed in their abundance before and after 1080 was applied to the Wilberforce site in 2012.

Table S4. Generalised linear mixed effect outputs of modelled changes in relative possum abundance over time in untreated sites.

Table S5. Generalised linear mixed effect output of two models testing how mouse abundance changed at sites on the (a) East and (b) West Coasts over time.

Table S6. Generalised linear mixed effect outputs of modelled relative rat abundance over time at the Mt Alexander site (1080-treated, West Coast).

Table S7. Summarised raw averages of bird count data (mean per 5-minute count) separated by monitoring period, species, and site.
Veltman CJ, Westbrooke IM 2011. Forest bird mortality and baiting practices in New Zealand aerial 1080 operations from 1986 to 2009. New Zealand Journal of Ecology 35: 21-29.

Veltman CJ, Westbrooke IM, Powlesland RG, Greene TC 2014. A principles-based decision tree for future investigations of native New Zealand birds during aerial 1080 operations. New Zealand Journal of Ecology 38: 103-109.

Westbrooke IM, Powlesland RG 2005. Comparison of impact between carrot and cereal 1080 baits on tomtits (Petroica macrocephala). New Zealand Journal of Ecology 29: 143-147.

Westbrooke IM, Etheridge ND, Powlesland RG 2003. Comparing methods for assessing mortality impacts of an aerial 1080 pest control operation on tomtits (Petroica macrocephala toitoi) in Tongariro Forest. New Zealand Journal of Ecology 27: 115-123.

Witmer GW 2005. Wildlife population monitoring: some practical considerations. Wildlife Research 32: 259-263.

Wright J 2011. Evaluating the use of 1080: predators, poisons and silent forests. Wellington, New Zealand, New Zealand Parliamentary Commissioner for the Environment. 85 p.

Table S8. Generalised linear mixed effect output of models testing how relative bird abundance changed over time.

Figure S1. Coefficients (mean \pm confidence intervals) for each bird species from GLMMs testing for effects of time, treatment, and time $\mathrm{x}$ treatment.

The New Zealand Journal of Ecology provides online supporting information supplied by the authors where this may assist readers. Such materials are peer-reviewed and copy-edited but any issues relating to this information (other than missing files) should be addressed to the authors. 